\title{
Ore formation and PGE prospectivity of the Fedorova-Pana Layered Complex, Kola Region, Russia
}

\author{
N. Yu. Groshev ${ }^{1 *}$, A. U. Korchagin ${ }^{2}$, A. N. Ivanov ${ }^{1}$ \\ ${ }^{1}$ Geological Institute, Kola Science Centre, Russian Academy of Sciences, 184209 Apatity, Russia \\ ${ }^{2}$ JSC Pana, 184209 Apatity, Russia \\ *Corresponding author e-mail: nikolaygroshev@gmail.com
}

Summary Ore formational models of contact- and reef-style platinum-group element (PGE) mineralization of the Fedorova-Pana Layered Complex are briefly considered including some prospecting recommendations.

\section{Introduction and background to current research}

The Fedorova-Pana Complex is the most thoroughly studied among the layered intrusions of the Kola region in terms of PGE. It contains four PGE deposits (Fig. 1). The large Fedorova Tundra deposit is confined to a 300-m-thick unit of varied-textured mafic rocks with sulfide disseminations in the basal portion of the Fedorova intrusion, in the west of the complex. To the east, economic PGE mineralization occurs as thin layers of disseminated sulfides within rhythmic interlayering of leucocratic, mesocratic and melanocratic cumulates occurring among homogeneous gabbronorites of the West Pana intrusion. Relatively small deposits have been explored at the North Kamennik and Kievey areas, respectively. Thin interlayers of unevenly distributed along strike sulfide dissemination continue further to the east. The East Chuarvy deposit is confined to the contact between two megacyclic units of the East Pana intrusion. The authors who took part in the discovery and initial geological study of these deposits discuss here some of the proposed ore formational models with an emphasis on their use in prospecting.

\section{Research questions at hand}

The recently discovered PGE deposits in the Fedorova-Pana Complex have triggered major scientific debate. Firstly, the origin of contact-style PGE mineralization remains unresolved. An example is the high-tonnage Fedorova Tundra deposit with characteristic relatively low concentrations of precious metals $(0.08 \mathrm{ppm} \mathrm{Au}, 0.29 \mathrm{ppm} \mathrm{Pt}$ and $1.20 \mathrm{ppm} \mathrm{Pd})$. Studies of similar deposits (Monchegorsk, Portimo) show that percolation of PGE-enriched sulfide droplets through partially molten cumulates of the near-contact zone of the intrusion is one of the key processes in the formation of such ores (Karykowski et al. 2018). This process is largely facilitated by the long-lived nature of the magmatic system and preheating of country rocks during early intrusive phases, due to which the near-contact zone become fluid-enriched lowering the melting point of intercumulus material in incompletely solidified rocks. As a result, a thick zone of cumulates $(50-100 \mathrm{~m})$ becomes permeable to sulfide liquid, which accumulates in its lower part by gravity. Since the mineralized varied-textured mafics at Fedorova Tundra, forming the basal intrusive breccia, have cross cutting relationships with the overlying rocks at all places (Groshev et al. 2019), it is suggested that the Fedorova intrusion mineralization is the result of additional entrainment of metal enriched magma from depth. 


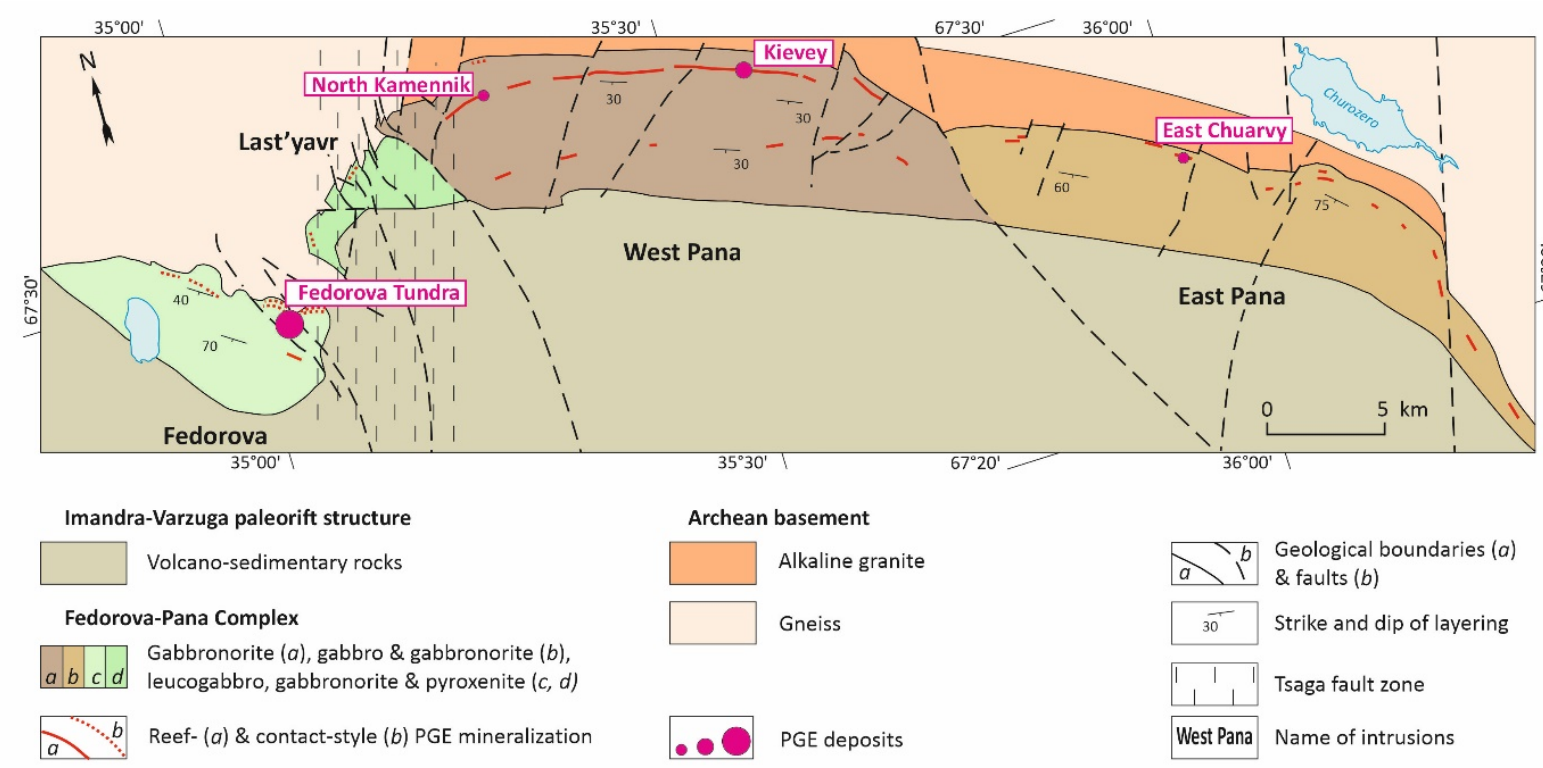

Figure 1. Simplified geologic map of the Fedorova-Pana Complex, showing the location of PGE deposits. Modified after (Groshev et al. 2019).

The remainders of the Fedorova-Pana deposits belong to another genetic type, characterized by laterally extensive thin ore bodies of disseminated sulfides with higher PGE concentrations (3-5 ppm). There are eight main hypotheses for reef-style PGE mineralization (Maier et al. 2018), addressing questions about reasons for sulfide immiscibility (mixing of magmas / contamination with crustal material / pressure increase), localization of the main oreforming process (observed magma chamber / deep magma chamber), mechanisms of PGE concentration (injection of enriched sill, remobilized from the observed chamber or originating from depth / PGE transfer by fluids / hydrodynamic sorting).

\section{Future prospects}

\subsection{Fedorova Tundra deposit}

The deposit is considered to have formed as a result of "out-of-sequence" injection (Fig. 2A) of the ore-bearing basal unit of the intrusion (Schissel et al. 2002; Dubrovskiy and Rundkvist 2008; Groshev et al. 2009, 2021), although it contradicts the results of studies of contact-style PGE mineralization in other layered complexes (Karykowski et al. 2018). Further development of this model requires new high-precision dating of the rocks to date specific layers of the intrusion. Prospecting should target potential continuations of the orebody to depth (see Fig. 1 in Groshev et al. 2021).

\subsection{North Kamennik deposit}

The North Kamennik deposit belongs to the so-called North PGE Reef of the West Pana intrusion (Korchagin et al. 2016). Initial prospecting revealed an outcrop with up to $13 \mathrm{ppm}$ PGE. However, a drillhole located $100 \mathrm{~m}$ from this outcrop intersected only unmineralized rocks. Subsequently, it was found that PGE mineralization is unevenly distributed in this part of the reef and is mainly concentrated in synforms of the ore-bearing horizon, which form channels in a plan view. PGE mineralization gradually disappears towards corresponding antiforms of the horizon (Fig. 2B). 


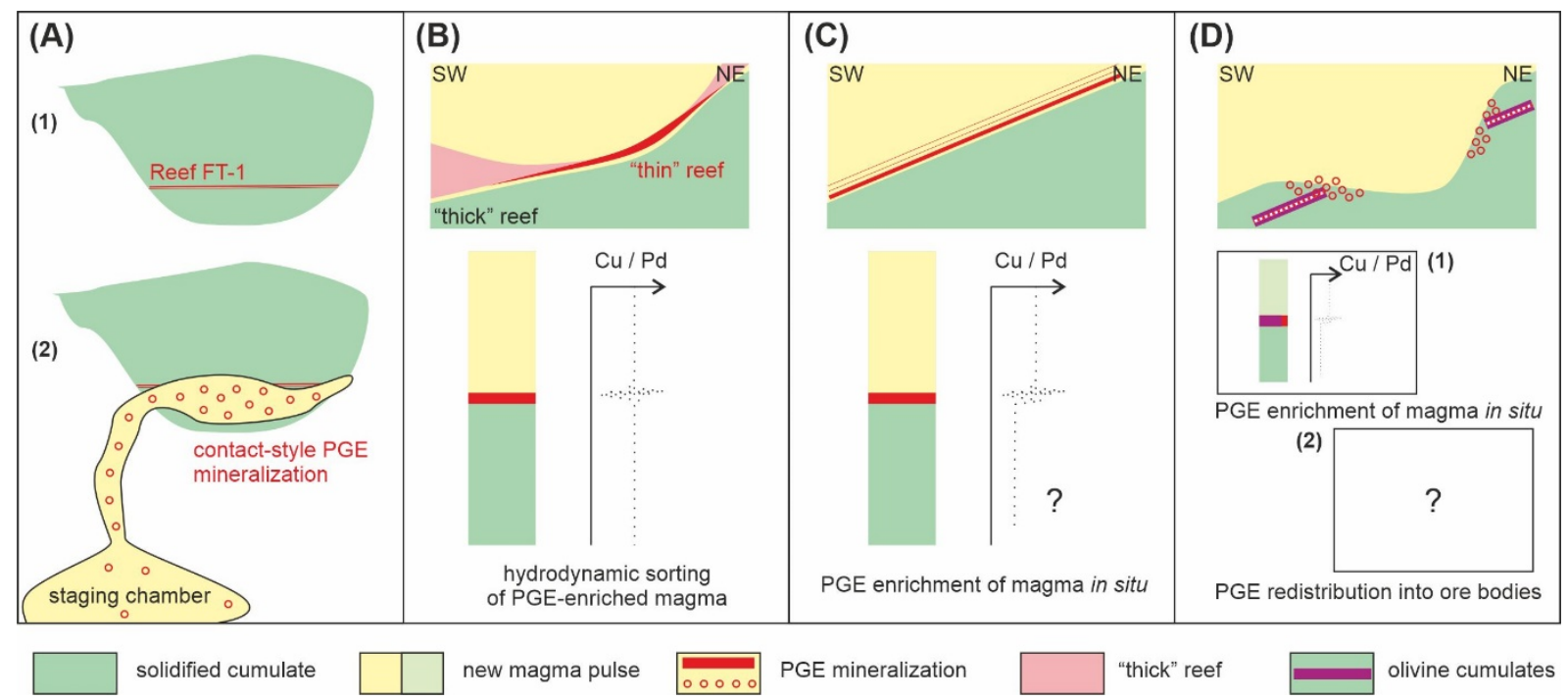

Figure 2. Sketched models of ore formation for the Fedorova-Pana deposits. (A) Fedorova Tundra. (B) North Kamennik. (C) Kievey. (D) East Chuarvy.

The mineralization in the synform can have a thickness of $5 \mathrm{~m}$ at a PGE grade of 3-10 ppm (drill hole 124). In the nearby antiform (drill hole 119), PGE concentrations between 40 to $200 \mathrm{ppb}$ are observed over a 50-m-thick interval, reaching $1000 \mathrm{ppb}$ in a few samples towards the base. Thus, the example of the North Kamennik deposit, which has "thin" and "thick" reef facies (Fig. 2B), apparently indicates an essential role of hydrodynamic sorting in the formation of reef-style PGE mineralization. To constrain the origin of the "thick" reef, it is necessary to conduct detailed geochemical sampling of drill holes.

\subsection{Kievey deposit}

The 5-km-long Kievey deposit is the most explored target of the North PGE Reef. Mineralization, containing on average $0.15 \mathrm{ppm} \mathrm{Au}, 0.53 \mathrm{ppm} \mathrm{Pt}$ and $3.32 \mathrm{ppm} \mathrm{Pd}$, is almost continuously traced along the strike of the ore-bearing horizon dipping to the southwest at an angle of $30^{\circ}$. The mineralization was drilled in detail to a depth of $250 \mathrm{~m}$, with several intersections measuring up to $500 \mathrm{~m}$. The mineralization is associated with melanocratic rocks at the bases of melanorite-gabbronorite-anorthosite cycles of the ore-bearing horizon, suggesting a link to magma replenishing events. Sampling data, in particular variations in chalcophile elements and $\mathrm{Cu} / \mathrm{Pd}$ ratio (Groshev 2020), suggest that the mineralization formed in situ (Fig. 2C). This is an important difference to the North Kamennik deposit (Groshev, 2021, unpublished data) which has mantle-level PGE concentrations and practically the same $\mathrm{Cu} / \mathrm{Pd}$ ratio in the underlying and overlying rocks, not revealing the enrichment process inside the chamber and, conversely, indicating sulfide liquid enrichment with PGE in an intermediate magma chamber at depth. This contradiction should be resolved because of a comparative study of a series of deposit sections using drill cores. A scientific drill hole at the Kievey deposit with an intersection of the ore body at a depth of $1000 \mathrm{~m}$ may be of particular interest.

\subsection{East Chuarvy deposit}

The East Chuarvy deposit is confined to the contact of the megacyclic units GNZ1 and GNZ2 in the East Pana intrusion. The mineralized rocks containing on average $2.43 \mathrm{ppm} \mathrm{Pt}, 5.17 \mathrm{ppm}$ $\mathrm{Pd}$ and $0.29 \mathrm{ppm} \mathrm{Au}$ were studied for $1200 \mathrm{~m}$ along strike and to a depth of $500 \mathrm{~m}$ (Kalinin 2021). The megacyclic unit GNZ2 has an erosional relationship with the underlying rocks of 
the GNZ1, represented by gabbronorites with several horizons of olivine gabbronorite. The ore body dipping to the southwest at an angle of $70^{\circ}$ has an extremely complex shape. The richest portions are found in areas where the GNZ2 rocks are in contact with the GNZ1 olivine gabbronorites, which are believed to be a source of ore material redistributed and concentrated because of the intrusion of magma from the GNZ2 megacycle. This model has not been previously described in the literature and requires a comprehensive study.

\section{Acknowledgements}

The authors are grateful to Prof. Wolfgang Maier for discussion of ore formation models for the North Kamennik and East Chuarvy deposits. The research was supported by the Ministry of Science and Higher Education of the Russian Federation (project 0226-2019-0053).

\section{References:}

Dubrovskiy MI, Rundkvist TV (2008) Petrology of the Early Proterozoic platinum-bearing Fedorova tundra massif (Kola Peninsula). Zap RMO CXXXVII:20-33

Groshev NY, Nitkina EA, Mitrofanov FP (2009) Two-phase mechanism of the formation of platinum-metal basites of the Fedorova Tundra intrusion on the Kola Peninsula: New data on geology and isotope geochronology. Dokl Earth Sci 427:1012-1016. https://doi.org/10.1134/S1028334X09060270

Groshev NY, Rundkvist TV, Karykowski BT, et al (2019) Low-sulfide platinum-palladium deposits of the Paleoproterozoic Fedorova-Pana Layered Complex, Kola Region, Russia. Minerals 9(12):764 https://doi.org/10.3390/min9120764

Groshev NY (2020) A genetic approach in exploration of platinum-palladium deposits on the Kola Peninsula. Vestn KSC RAS 2:29-35

Groshev NY, Stepenshchikov DG, Karykowski BT (2021) An experiment on thermal modelling of the Paleoproterozoic Fedorova layered intrusion, Kola Region, Russia: implications for the origin of contact style PGE mineralisation. This volume

Kalinin AA (2021) Precious metal mineralization in the East Pansky layered massif. This volume

Karykowski BT, Maier WD, Groshev NY, et al (2018) Critical controls on the formation of contact-style PGE-Ni$\mathrm{Cu}$ mineralization: Evidence from the paleoproterozoic Monchegorsk Complex, Kola Region, Russia. Econ Geol 113:911-935. https://doi.org/10.5382/econgeo.2018.4576

Korchagin AU, Goncharov YV, Subbotin VV, et al (2016) Geology and composition of the ores of the low-sulfide North Kamennik PGE deposit in the West-Pana intrusion. Ores Met 1:42-51

Maier WD, Halkoaho T, Huhma H, et al (2018) The Penikat Intrusion, Finland: Geochemistry, Geochronology, and Origin of Platinum-Palladium Reefs. J Petrol 59:967-1006. https://doi.org/10.1093/petrology/egy051

Schissel D, Tsvetkov AA, Mitrofanov FP, Korchagin AU (2002) Basal Platinum-Group Element Mineralization in the Federov Pansky Layered Mafic Intrusion, Kola Peninsula, Russia. Econ Geol 97:1657-1677. https://doi.org/10.2113/gsecongeo.97.8.1657 